\title{
TRANSFORMATION OF WOMEN POLITICIANS IN PARLIAMENT
}

\author{
Evi Muafiah \\ Islamic State Institute of Ponorogo \\ email: muafiahevi@gmail.com
}

\begin{abstract}
Women's representation in politics in Indonesia has been secured despite inequal percentage compared to the men. For instance, the results of the 2019 legislative elections for women only accounted for $20.5 \%$ or 118 seats of the 560 existing seats. On the other hand, it seems that the performance of women in parliament is also questionable. Thus, this research was conducted to find out and understand how was the performance of women politicians, their contribution to women empowerment and the obstacles they faced. This descriptive-explorative qualitative research was conducted in Ponorogo as a district in the former Residency of Madiun which always gets the highest number of women politicians in each elections until 2019. The research subjects were selected using purposive sampling toward women legislature members of DPRD Ponorogo. Meanwhile, the data was obtained through interviews, observation, and documentation. Furthermore, for the data analysis the author employed Harvard gender analysis and used data triangulation as one of the data verification techniques. The results of this study concluded that the performance of women legislative members was less satisfactory. This can be seen from 3 aspects; responsiveness, accountability and effectiveness. In addition, some obstacles they faced are (a) the strong patriarchal culture in the legislative environment, (b) weak coordination among women legislative members, (c) patterns of relationships that are built on a transactional basis, and (d) politically charged programs.
\end{abstract}

Keywords: women politicians, DPRD Ponorogo, performance, contribution. 
الملخص: إن تمثيل النساء في السياسة معتبر إلا أن نسبته مل تكن متوازنة بالر جال. وإلى الآن

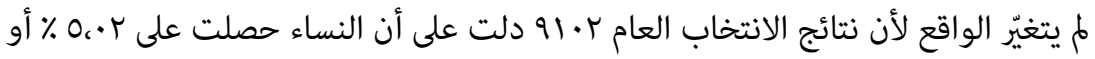

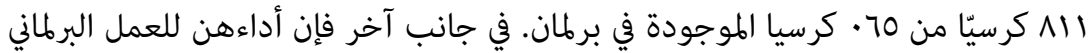

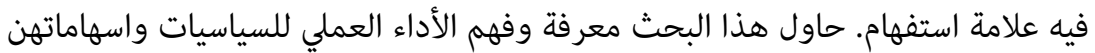
في تقوية النساء والعوائق التي تواجههن كفاحهن في حمل طمات طموحات وحات وحاجات أتباعهن.

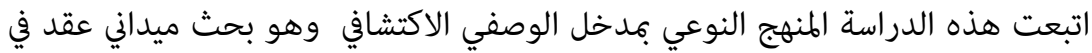

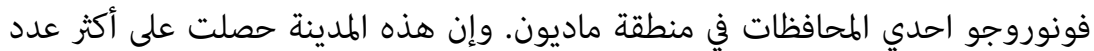

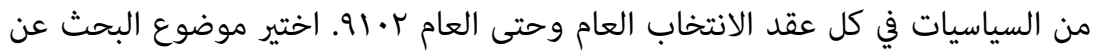

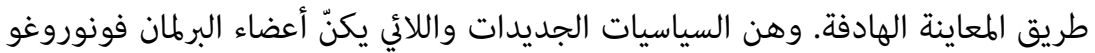

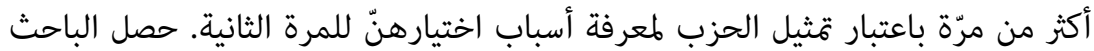

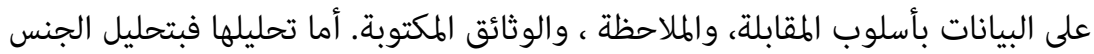

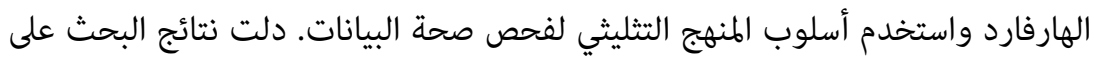

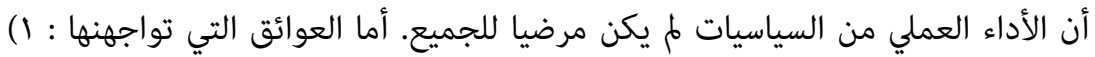

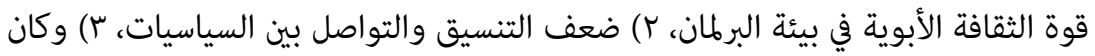
التواصل بينهن والرعية على أساس المعاملات، ع) والأنشطة المقامة فيها مضامن سياسية.

Abstrak: Keterwakilan perempuan dalam politik sudah diperhitungkan meskipun prosentasenya belum seimbang. Hingga sekarangpun prosentase itu tetap tidak seimbang, karena hasil pemilu legislatif 2019 perempuan Indonesia hanya mendapatkan 20,5\% atau 118 kursi dari 560 kursi yang ada. Di sisi yang lain, nampaknya kinerja perempuan dalam parlemen juga dipertanyakan. Penelitian ini dilakukan untuk mengetahui dan memahami bagaimana kinerja politisi perempuan, kontribusi mereka terhadap pemberdayaan perempuan serta kendala yang mereka hadapi dalam memperjuangkan aspirasi dan kebutuhan konstituennya. Penelitian kualitatif yang bersifat deskriptif-eksploratif dan merupakan penelitian berjenis lapangan ini dilakukan di Ponorogo sebagai kabupaten di eks Karesidenan Madiun yang selalu memperoleh jumlah politisi perempuan terbanyak dalam setiap pemilu hingga tahun 2019. Subyek penelitian dipilih secara purposive sampling, yaitu para perempuan anggota legislatif yang baru sekali dan yang sudah lebih dari satu kali menjadi anggota DPRD Ponorogo dengan mempertimbangkan keterwakilan partai serta untuk mengetahui 
mengapa bisa terpilih kembali. Data diperoleh dengan teknik wawancara, observasi dan dokumentasi, sedangkan analisis data menggunakan analisis gender Harvard dan menggunakan triangulasi data sebagai salah satu teknik pemeriksaan keabsahan datanya. Hasil penelitian ini menyimpulkan bahwa kinerja anggota legislatif perempuan kurang memuaskan. Beberapa kendala yang dihadapi adalah (a) kuatnya budaya patriarkhis di lingkungan legislatif, (b) lemahnya koordinasi antar anggota legislatif perempuan, (c) pola hubungan yang dibangun melalui dasar transaksional, dan (d) program-program bermuatan politis.

\section{INTRODUCTION}

General election in Indonesia has just passed. As in previous election, women's representation in parliament has not met the $30 \%$ quota. Women politicians in the 2019 legislative election only ensured $20.4 \%$ or 118 seats out of 560 existing seats, whereas the population of Indonesian women is the majority. ${ }^{1}$ Not only at the central level, the Regional People's Representative Council (DPRD) and the Regency / City DPRD also experiences the same problem. The results of the 2009 Election and the representation of women in the Provincial DPRD on average was $16 \%$, while the Regency / City DPRD was $12 \%{ }^{2}$

However, this presence is continuously endeavored to increase a balanced representation of women with the total population in Indonesian politics field and in any public office. This appeal was encouraged by the desire of some communities to provide opportunities for women to take part in the public area.

As a result, the government through the General Election Commission $(K P U)$ required that each political party formulated its $30 \%$ legislative candidate from women. In fact, the decision created a significant impact. For instance, in the 2004 election, of the $30 \%$ proposed, there were 61 or around $11.09 \%$ of 550 passed

1 Loura Hardjaloka, "Potret Keterwakilan Perempuan dalam Wajah Politik Indonesia Perspektif Regulasi dan Implementasi," Jurnla Konstitusi 9, no. 2 (2012): 2.

2 Pusat Kajian Ilmu Politik, Naskah Rekomendasi Kebijakan: Representasi Perempuan dalam Regulasi Partai Politik dan Pemilu (Jakarta: Pusat Kajian Ilmu Politik Universitas Indonesia, 2010), 3. 
to parliament. This increased from the previous number of only 45 or $9,2 \%$ in the 1999 election. $^{3}$ In the 2014 period it increased again to 101 members or around $17.86 \%$ and in 2019 it increased again to $20.5 \%, 118$ from $560 .^{4}$

But on the other hand, the performance of women in parliament is still questionable. Have women representatives in parliament been able to produce policies that benefit for women? Have they been able to show good performance in parliament? These questions, of course, are very likely to be the basis for the community to re-elect or not nominate them. Talking about politics and women is ambivalent. In one side, politics involves itself in a world full of intrigue, a media to show off the power, a place to gain, retain, and expand influence in any way that needs strength and masculinity. On the other hand, women that identical with softness and family oriented need to join into the harsh world of politics as an effort to develop equality and justice in the relations of men and women in the public sphere. Nadezhda Shvedova in one occasion stated that women throughout the world at every socio-political level felt themselves under-represented in parliament and far from being involved decisions making. Women who want to join politics find that the politic, public, culture and social spheres are often hostile to them. ${ }^{5}$

Indonesian women have actually obtained the right to vote and be elected since 1945. History records that in 1950 women were first appointed to become minister. In 1955 women were able to take part in the election ${ }^{6}$ The same recognition between the rights of women and men in the life of the nation and state has been explicitly recognized. ${ }^{7}$ However, until now women's representation in various formal political institutions is still very low. Throughout the elections the increasing representation of women in politics is very slow and has never reached $30 \%$. Among the impacts are the low ability to

3 Sidik Pramono, Meningkatkan Keterwakilan Perempuan, 1 (Jakarta: Kemitraan bagi Pembaruan Tata Pemerintahan, 2011), 1.

4 Dian Erika Nugraheny, "KPU: 118 Perempuan Terpilih Jadi Anggota DPR 2019-2014,” Republika.co.id, September 2019.

5 Nadezhda Shyedoya, Perempuan di Parlemen (Jakarta, 1999), 17.

6 Ani Widyani Soetjipto, Politik Perempuan Bukan Gerhana (Jakarta: Penerbit Buku Kompas, 2005), 1.

7 Zaenal Mukarom, "Perempuan dan Politik: Studi Komunikasi Politik Tentang Keterwakilan Perempuan di Legislatif," Mediator 9, no. 2 (2008): 1. 
fight for related issues women and laws that have an impact on the plight of women in Indonesia. While the most prominent consequence of this condition is the low ability to access women in all stages of development, from the planning, implementation, monitoring and evaluation stages of development results and access to enjoy the results.

Now days in the era of regional autonomy, this condition causes a number of public policies, including the regional budget $(A P B D),{ }^{8}$ which does not reach the basic needs of women, such as the protection of human rights, security, education, health, labor, and the environment, which in turn leads to a low quality of life for women.

Based on the results of a survey conducted by the Woman Research Institute (WRI) of 160 respondents, namely members of the Indonesian Women's Parliamentary Caucus (KPP RI) as well as members of Commission II and Commission VIII of the DPR, in the period March 12 to April 20, 2012, showed that women legislative members quite diligently attending meetings in the Council, both plenary meetings, commission meetings, and meetings on other Council equipment. Even so, women legislators have not yet made a maximum contribution to policy making in parliament. ${ }^{9}$ From the findings of WRI, women with activist backgrounds have high sensitivity to raise gender issues in parliament. ${ }^{10}$

The number of women who take part in politics has not been able to offer a different political culture. Women have not been able to show themselves as agents of change. The weak role of women in parliament occurs because the capabilities of women who qualify for parliament are not well tested. Most women who are elected and take part in the world of formal politics today come from political dynasties or popular figures such as artists. Because the recruitment mechanism is colored by the scent of nepotism, plus the regeneration process is not running, the increase in the number of women in the

${ }^{8}$ Indonesia as a country with a majority of female population should implement a gender responsive APBD as it has been done by Australia, Afrika Selatan, Tanzania and Philipina. See Sri Mastuti and Rinusu, APBD Responsif Gender (Jakarta: CiBa, 2003), 38-40.

9 Luky Sandra Amalia, Perempuan, Partai Politik, dan Parlemen di Indonesia: Suatu Analisis (Jakarta: PT. Gading Inti Prima, 2012), 266.

${ }^{10}$ Rahayuningtyas, "Perempuan dan Pembuatan Kebijakan di DPR RI" (Presentation, April 26, 2012). 
parliament is not directly parallel to quality. ${ }^{11}$ The role of women in legislative, supervisory and budgetary functions is not maximal. As a result, parliamentary products do not accommodate the aspirations and interests of women. The poor performance of legislative women does not only occur in the central level, but also occurs in the regional level in Indonesia, such as Ternate, Papua, Aceh, Nusa Tenggara and so on. ${ }^{12}$

Henceforth, this research was conducted to find out and understand how the performance of women DPRD members in Ponorogo, including their contribution to women's empowerment and the obstacles they face in fighting for the aspirations and needs of their constituents. This locus and focus was chosen because Ponorogo is an area in the former Residency of Madiun which always gets the most votes for women in every election until 2019 and the success of several women members of the legislat ure who occupy the Regional Legislative Assembly DPRD seats more than once. In 2019-2024 period, there are 7 women legislatures from 45 or $15,5 \% .{ }^{13}$

\section{WOMEN POLITICIANS IN PARLIAMENT}

The term parliament in European means talking of state matters. At first, the parliament consisted of kings, nobles, landlords and religious leaders. But in the XIV century the meeting developed into a media liaising between the king and his society whom were represented to the royal officials. They were asked for information or advice on political and administrative issues that were considered to influence the development of the kingdom in the future. ${ }^{14}$

In Indonesia, parliament is manifested as Legislative Assembly (DPR). The history of $D P R$ RI (Republic of Indonesia) itself is

${ }^{11}$ Amalia, Perempuan, Partai Politik, dan Parlemen di Indonesia: Suatu Analisis, 267-269.

12 Amalia, 269.

${ }^{13}$ Komisi Pemilihan Umum Kabupaten Ponorogo, "Pengumuman Nomor: 701 /PL.01.9-Pu/3502/KPU-Kab/VII/2019 Tentang Pengumuman Penetapan Calon Terpilih Anggota Dewan Perwakilan Rakyat Daerah Kabupaten Ponorogo Pemilihan Umum Tahun 2019," July 22, 2019.

${ }^{14}$ Sri Puji Nurhayati, Kinerja Lembaga Legislatif (Studi Analisis Kinerja DPRD Kota Medan Periode 2004-2009) (Sumatera Utara: Universitas Sumatera Utara, 2010), 8. This is different from America which uses the term legislat ure which implies the law makers. Bambang Cipto, Dewan Perwakilan Rakyat (Jakarta: RajaGrafindo Persada, 1995), 2. 
established since the formation of Komite Nasional Indonesia Pusat (KNIP) by Presidentin August 29, 1945, which is 12 days after the Proclamation of Indonesian Independence. The date is then commemorated as the day of DPR RI's birth. Until 2014, we have had $18 D P R .{ }^{15} D P R$ as a board of legislative has representatives at the provincial and district/city level called Regional Legislative Assembly (DPRD). As part of Indonesian parliament's existence, $D P R D$ must pay attention to factors that can establish harmony between the interests of the society members they represent and the interests of various other groups. These factors include:

1. Integrity and ability or skills of legislature members.

2. The relationship between the board and society which is reflected in the prevailing system of representation.

3. The board of legislative's organizational structure which is a formal framework for the members' activity to act as society's representative.

4. Relationship that is reflected in the mutual influence between the board of legislative and executive and other institutions as regional government units, as well as the relationship of the agency with the same institution at a higher level of hierarchy. ${ }^{16}$

$D P R D$ has legislative, supervisory, budgetary, official, international and representative functions. $D P R D$ as one element of local government is a legislative function that represents the interests of the people's aspirations. While the rights and obligations are to carry out consistently the provisions of the People's Consultative Assembly $(M P R)$ and obey all prevailing laws and regulations. Then, $D P R D$ together with the regional head compiles the $A P B D$ for the needs of the region within the limits of the authority devolved to the regions or implements laws and regulations which are assigned to the regions. ${ }^{17}$

Women's struggle to obtain a quota in the election has paid off with the inclusion of a minimum nomination $30 \%$ quota, although many people consider the law as a "half-hearted" policyor known

15 "Dewan Perwakilan Rakyat," accessed November 16, 2019, http://www.dpr. go.id/.

${ }^{16}$ Arbi Sanit, Perwakilan Politik di Indonesia (Jakarta: Rajawali Press, 1985), 205.

${ }^{17}$ Arbi Sanit, 20. 
by affirmative action. During the Post-Suharto era, the policy has been used 3 times in election 2004 through constitution or UU No $12 / 2003$ which states that women's representation in the legislature is at least $30 \%$ by combining the quota system and the serial number rules. The result was $11.09 \%$ for female votes. In 2009, the election was regulated by UU no. 10/2008 and 2014 was regulated by UU no $8 / 2012 .{ }^{18}$ The set rule has been developed that is in the list of prospective candidates every 3 (three) prospective candidates, there is at least 1 (one) woman, known aszippersystemand produce $18 \%$ and $17 \%$ respectively. ${ }^{19}$

In comparison, the quota system has also been applied volunt arily by several countries. Sweden for instance, which in 1994 the Social Democratic Party began to impose a "Zebra Horse Strip" system, which would place male and female legislative candidates alternately. Meanwhile, Norway in 1983 the Labor Party implemented a 40\% quota for women Likewise, Denmark applied in $1988 .{ }^{20}$

\section{PERFORMANCE AND CONSTRAINT OF DPRD INSTITUTION}

Performance is a depiction of the achievement level toward implementation of an activity, program or policy in realizing the goals, objectives and vision and mission of an organization as outlined in the formulation of the organization's strategic scheme. ${ }^{21}$ The term performance is often used to see the individuals' or groups' level of success. This performance can be known if an organization has established success standards. ${ }^{22}$ Performance can also be said as the result that can be achieved by a person or group of people in an organization based on their respective authorities and responsibilities

18 Sidik Pramono, Meningkatkan Keterwakilan Perempuan (Jakarta: Kemitraan bagi Pembaruan Tata Pemerintahan, 2011).

${ }^{19}$ Elisabeth Anita Dhewy Haryono, "Bagaimana Wajah Caleg Perempuan dalam Pemilu 2014?," Yayasan Jurnal Perempuan, May 2014, 10.

${ }^{20}$ MB. Wijaksana, Modul Perempuan untuk Politik (Jakarta: Yayasan Jurnal Perempuan, 2004), 10.

${ }^{21}$ Irham Fahmi, Manajemen Kinerja: Teori dan Aplikasi (Bandung: Alfabeta, 2013), 2 .

${ }^{22}$ Mohamad Mahsun, Pengukuran Kinerja Sektor Publik (Yogyakarta: BPFE, 2013), 25. 
in an effort to achieve the goals of the organization concerned legally, not violating the law and in accordance with morals and ethics. ${ }^{23}$

This research applied organizational performance measurement related to accountability, responsiveness and effectiveness as follows: ${ }^{24}$

1. Accountability that is an ability to explain the condition experienced including the decision making and other activities. In this dimension, performance is not only seen through organization's internal side, but also through external side, these are value and norm of society. Every chosen stakeholder must be responsible toward all decided policy, even their words and behavior. ${ }^{25}$

2. Responsiveness can be understood as an ability to communicate well in voicing society's aspiration or complaint.

3. Effectiveness of performances showed by board of DPRD members can be perceived through how far they can carry out the functions inherent in their bodies, or the functions of legislation, supervision and budget. ${ }^{26}$

$D P R D$ members are said to work their best if their performance always increases during the required period. But apparently there are influential things toward their performance as follows. ${ }^{27}$

1. Internal factor, which consist of rules, data and information as well as the quality of $D P R D$ members. A rule is made with the aim that all tasks can be carried out smoothly and in an orderly manner. However, if the regulation is too rigid, it will obstruct the implementation of the task itself. Then, the set rules should not become obstacles for the work of $D P R D$. Almost all regions

${ }^{23}$ Suyudi Prawirosentono, Kebijakan Kinerja Karyawan: Kiat Membangun Organisasi Kompetitif Menjelang Perdagangan Bebas Dunia (Yogyakarta: BPFE, 1992), 2.

${ }^{24}$ Agus Dwiyanto, Reformasi Birokrasi Publik di Indonesia (Yogyakarta: Pusat Studi Kependudukan dan Kebijakan, 2002), 47-49.

${ }^{25}$ Afan Gaffar, Politik Indonesia: Transisi menuju Demokrasi (Yogyakarta: Pustaka Pelajar, 2000), 7.

${ }^{26}$ In accordance to the function of DPRD Ponorogo based on Regulation of DPRD Ponorogo number 01 of 2010 concerning the Rules of Procedure of DPRD Ponorogo. Wahyudi Komorotomo, Sistem Informasi Manajemen dalam Organisasi Publik (Yogyakarta: Gadjah Mada University Press, 1998), 25.

${ }^{27}$ Riswandha Imawan, Faktor-Faktor yang Menghambat Usaha Optimalisasi Peran Dewan Perwakilan Rakyat RI dalam Fungsi Legislatif, dalam Sistem Politik Indonesia, (Jakarta: Rajawali Press, 1993), 79. 
experience the same thing that is the lack of information and data compare to the executive's information and data. But this situation is ultimately understandable because the executive is always deals with the state matters. Usually, the executives will get more data and information than the legislature. Furthermore, it influences the performance of DPRD members. Meanwhile, in general, the executive's background of education is higher than legislature's. Especially, the woman legislature whose recruitment is based on party coercionin order to reach $30 \%$ standard quota.

2. External factors include the mechanism of the electoral system and the executive-legislative position. Change in the electoral mechanism always has the unpleasant effect, even though the goal is to improve the election itself. In the Indonesian government system, the legislative occupies a position as an executive partner. In fact they tend to co-opt where the executive position is stronger than the legislature. This condition is very influential on the implementation of the tasks and functions of each institution. ${ }^{28}$

\section{THE PERFORMANCE OF PONOROGO WOMEN'S POLITICIANS}

\section{Perception of Women's Condition}

According to women with low education, their lives are less prosperous. Their life choices are very limited, such as working as a female worker $(T K W)$ overseas or in the mother land to help their husband earn a living with a substantial salary compared to working in the village. Therefore, economically, many women become rich and can improve the family welfare. On the other hand, educated women have contributed to the development even though they are still doubtful and even afraid of joining practical politics.

However, both views seem to meet similarity in context where women do not have enough opportunities to take part in politics. Empowering them from the political side is actually the same as fighting for the whole fate of women and it can increase their role in society.

${ }^{28}$ Nurhayati, Kinerja Lembaga Legislatif (Studi Analisis Kinerja DPRD Kota Medan Periode 2004-2009), 29. 


\section{Perception of Women Politicians about Women and Politics}

Politic is not suitable for women, because politic is cruel and dirty. Politic is also full of fraud, frightening and it is the world of men. However, behind these there is a struggle that must be upheld and it is very interesting. Some of the reasons put forward by women who are reluctant to do politics are dirty world, cannot live full of intrigue and they are still struggling with domestic matters. People already think that politics is hard, dirty, and full of fraud.

All women members of parliament admitted that politics for women is inappropriate. Because politics is a world of men filled with violence, cruelty, dirty and deception. Women are creatures that are generally soft-mannered, and need love. Women who enter politics are strong, intelligent, and like challenges. According to them although politics is perceived as a world of men, it does not mean that women cannot enter politics.

\section{Condition of Women Politicians in DPRD Ponorogo}

The condition of the minority and the lack of quality are caused by the fact that they are not properly selected in the parliament, so that women who enter parliament are few in number and lacking in quality too. The $30 \%$ quota is only considered as a complement to sufferers, because there is no struggle from the party and the government. Women of parliament should exist, smart, and want to learn, otherwise they will be deemed non-existent by men. Politicians themselves sometime have been placed by the political party in the top ranking number, but because of their limited ability, so they are not elected. Actually, woman occupies a strategic position when she sits in parliament, she can fight for women's aspirations.

The description of the condition of women legislative members in the aforementioned resulted in very small contribution of women legislatures in voicing the aspirations of the community, especially women. The small number of women in parliaments left them powerless to propose and produce strategic issues about women's empowerment. The ability of women legislatures themselves is generally lack in the absence of a good selection mechanism from the party. Henceforth, their existence is no more as an adornment, or even considered absent. Indeed, the mandate of the law states that 
women's representation in parliament as much as possible reaches the affirmative action that is $30 \%$. But in practice the spirit was not well implemented in the party and the government.

\section{Contribution of Women Politicians toward Women Empowerment}

The contribution of women politicians in empowering women was not fully represented. They contributed only to the constituents or mass organizations that carried them. This situation was complemented by a number of obstacles that arose when these women politicians proposed something that has to do with women empowerment. For instance, every time they propose an empowerment program for women, their proposals are always cut off by male politicians. Their proposal was always countered or postponed first.

\section{The Role of Women Politicians in Increasing Concern for Women}

There was a striking difference when informants were asked about their role in raising concern or awareness for women. Two of them are really active to participate in women's group activities since before joining political parties and while being active as a member of the board. But there are also informants who have never been active in women's activities at all.

The role of several women legislative members in raising awareness for women includes; attend routine activities of fostered women's groups, for example Aisiyah, Persit (Union of Army Wives), Dharma Pertiwi (TNI-POLRI wife community), GOW or Gabungan Organisasi Wanita (Combined Women's Organization), KPPI or Kaukus Perempuan Politik Indonesia (Caucus of Indonesian Political Women), IWAPI or Ikatan Wanita Pengusaha Indonesia (Indonesian Women Entrepreneurs Association). There was an active role in the empowerment of women before being a council member, such as being a party sympathizer and also chairing the Dharma Wanita, followed by entering into practical politics while actively empowering members of Muslimat NU. Koalisi Perempuan Politik Indonesia or KPPI (Indonesian Political Women Coalition) also used as a forum to empower women and increase awareness of women 
by carrying out the making of regulations on migrant workers and trafficking.

Women politicians from PDIP said that PDIP is a constituent of mostly men, so empowerment is not only focused on women. In this party there are no special activities for women, although the central leadership is women. Women cadres try to be added, but most of them emerge from the wives of male cadres.

\section{Types of Women Empowerment Programs}

Most of planned programs are general to be enjoyed by the community. There are almost no programs specifically for women. The assumption is that these general programs can specifically be enjoyed by women.

Of the several programs implemented, it is important to note that these programs are generally given to the community or groups that during the election period are their constituents. So that it feels like reciprocation. For people who do not have closeness to parliamentarians, it is possible that the village will not get a program.

\section{Techniques for Accommodating Aspirations}

People's aspirations for all parliamentarians are inherent as an expression of their commitment as representatives of the people. Some women's parliaments have different ways in listening to the aspirations of the community, including: (a) attending the routine activities of the target groups while listening to their aspirations, (b) the cadres come to their homes and then immediately submit their complaints, (c) the cadres are collected later asked about complaints or problems that exist, (d) holding an aspiration net by gathering constituents or cadres, (e) meeting cadres in each sub-district, (f) attending musrenbang (development planning meetings), and (g) receiving direct visits or letters from the people who want to express their aspirations.

The informal way can be done personally or collectively. Collectively, they do it with fellow members of parliament who have the same chosen region. They collected data on all villages, divided regions, and mapped with their respective cadres. Hence, there is no a collision. During their visit to listen to these aspirations, most of them were only to accommodate the aspirations of cadres or their 
constituent organizations. People who express their aspirations are not specifically women. even though the community visited by women's organizations, usually the problems raised are physical development and economic sector development.

\section{Responsiveness in Resolving Conflict}

It seems that the responsiveness of women politicians in fighting for women can be disrupted by bureaucratic procedures, especially if the problems of society (women) enter through formal channels, and can drag on over the working period of parliamentarians who are mostly in the form of recess. They are guarding the issue so that it is always talked for a solution. Because every time a member of parliament meets, the agenda discussed is overwhelming and demands priority. If this women's issue is not guarded, then it can be buried and deemed unimportant.

However, the majority of the few women politicians do not have the power to oversee women's issues in the parliamentary session. These issues will be immediately cut and considered less important. Generally they pay more attention to general issues relating to the infrastructure development of their constituent areas. It could be that their enthusiasm for fighting for women is very high, because in the genre they are most responsible for women. Unfortunately, it was hampered even faded by bureaucratic power, party interests, the quality and quantity of women parliamentarians themselves.

\section{Contribution for Society, Party, and Women}

Some of the recognitions of women parliamentarians in contributing to the community, parties and women, such as: to the community(a)re-elected to parliament shows that they have succeeded in making a large contribution to the community, (b) channeling social funds to the community, and (c) realizing community needs for roads. While their contributions to the party include; (a) they deposit a certain percentage of their salary each month for their parties, (b) contribute more seats in parliament than the previous number of seats, and (c) fund with their own efforts in the electoral process. Their contribution to women's empowerment includes; (a) visiting women's organizations in each electoral district, (b) visiting every activity carried out by women's organizations, (c) forming farmer 
women's organizations, (d) conducting cadre processes for talented women in the political world.

\section{Obstacles Faced}

Some of the obstacles in implementing women's empowerment programs can be divided into two, namely internal obstacles and external obstacles. Internal obstacles include; (a) party conditions that are often noisy, (b) party policies that are more concerned with general programs rather than special programs for women. Meanwhile, the external obstacles are; (a) public opinion that parliamentarians are rich people, lots of money, so that they always ask for donations, (b) community programs demand for immediate realization, (c) journalists also often intimidate and demand for rations.

\section{Impressions during being Women Politicians}

Some of the impressions they felt related to their experience revealed that their involvement in politics as people's representative was actually very tiring. One side they had to deal with their own friends during the campaign, dealing with candidates from other parties, aspirations of the people that must be met on the one hand and dealing with the board forum and executive officials. On the other hand, they also face conflicts of interest with other parties in board meetings, mafias and so on. They also have to make legislation that is needed by the community. However, as they admit that if these things are undertaken with the intention of learning, adding knowledge and insight, seeking experience, then that fatigue will soon be restored, especially if the intention is to uphold justice and improve the welfare of society.

Whereas their messages for women were expressed in form; (a) invited women to rise up and be active in politics, (b) invited women to show their potential and ability so that they are not always left behind by men, and (c) the 30\% affirmative action rule for women's representation in parliament and in nominations must be obeyed, it seemed like an appeal, because the practice of party leaders and the government was less strict and did not provide facilities. 


\section{ANALYSIS OF PERFORMANCE, CONTRIBUTION, AND WORK OBSTACLE OF WOMEN POLITICIANS IN PONOROGO}

According to women, politics is dirty, cruel, deceptive and scary. It is not suitable for women because politics is the world of men. ${ }^{29}$ Actually, the points of view emerge as a stigmatized reason that women are weak, delicate, clean and do not like violence, while men are tough, and strong. This stigmatization might not be wrong, based on reality happened. However, perpetuating such views can worsen women's condition.

This stigmatization came from two directions, from men and from women themselves. According to the former, negative labeling of women consciously or unconsciously can result in increasing of disadvantaged positions for women. The next result is aconservativecultural view that strengthen the position of men and weaken women. While based on the latter, in the same unconscious conditions, women are willing to let the situation happened to them, without further thinking that such situation is detrimental. What happened in the previous discussion which illustrates that male parliamentarians are easily said that women's empowerment programs as an unimportant program, hence, when women parliamentarians propose an empowerment program it is always cut, showing two things; it is right that the program was deliberately deemed unimportant or indeed if the program was passed it was deemed not to be implemented properly. The fact showed that women parliamentarians themselves are not able to deal with the situation that crushes them. What will be seen in further analysis is a description of the limitations of women legislators in a dilemma situation, where they must fight for women, but on the other side they are faced with a parliamentary situation that is very strong with its patriarchal culture.

The performance of legislative members is measured by three (3) things; responsiveness, accountability and effectiveness. ${ }^{30}$ Responsiveness can be understood as a person's ability to capture

${ }^{29}$ Siti Nimrah and Sakaria, "Perempuan dan Budaya Patriarki dalam Politik (Studi Kasus Kegagalan Caleg Perempuan dalam Pemilu Legislative 2014 )," Jurnal The Politics 1, no. 2 (July 2015): 178.

${ }^{30}$ Ella Wargadinata, "Kualitas Pengukuran Kinerja Organisasi Publik," Sosiohumaniora 19, no. 2 (July 2017): 86-94. 
and respond to something around him. The responsiveness of one person to another varies in the alertness and form of the responses. Someone who has high responsiveness will always respond something quickly and vice versa. Therefore, the responsiveness of women parliamentarians in responding to women's problems is mainly determined by the extent to which women are aware of and empathetic to the condition of women in society. Unfortunately, what was done by women legislators regarding their responsiveness is very unsatisfactory. Responsiveness which is essentially satisfying the needs of the society seems to be less concerned. One important thing that needs to be raised in relation to this dimension is the need for a law on migrant workers and trafficking that is clearly needed by society, especially women. In fact, it has not yet been discussed. This is due to the notion that issues related to women are still considered less important. Maybe women legislators have struggled to realize the rules related to both things. However, because of their number as minority and the lack of ability, eventually the rule is still neglected.

Accountability is the external side of an organization contains the values and norms of society. ${ }^{31}$ Every organization that deals with society needs must have accountability to society. In this context, members of the legislature as a community who fight for society's need are required to be responsible of their work to the people, especially their existence is chosen by them. Their responsibility to the community is not only in the programs, but also in their words and behavior. Organizational performance is considered to have good accountability when the organization's implementation of activities does not conflict with existing rules in society. Thus, $D P R D$ is morally and factually responsible for the smooth running of the government for giving service to society.

What happened in this dimension showed that many things did not reflect good accountability for legislators. The legislative members, both women and men, were equally furious with some heads of villages who did not keep promises during the campaign where they promised to elect certain candidates, but at the time of voting they elected other candidates. These village heads would be returned by legislators by not giving them development programs or

${ }^{31}$ Kristian Widya Wicaksono, “Akuntabilitas Organisasi Sektor Publik,” Jurnal Kebijakan dan Administrasi Publik 19, no. 1 (mey 2015): 1. 
social assistance. This attitude of revenge in Indonesian politics is very common. This revenge sometimes did not consider whether the village was in need of development funds or not. According to the researcher, this phenomenon occurs because our political culture is a transactional culture, a culture of take and give, where people who make meritorious services will get the results. Therefore, they are not fully accountable to all levels of society because their responsibility was partial, only to regions or communities that did meritorious.

Likewise, it traces accountability through regeneration. Generally, they carry out regeneration to their wives, children or relatives, no matter they have the ability or lack of it. This kind of regeneration certainly becomes blurred. Because this dimension of accountability requires someone to have skills since they are chosen by society, they must be responsible to the society as well. The cadres who came from the family path would be difficult to perform the accountability, moreover their appearance is based on the amount of funds they have and the family's big name.

Other performance dimensions are measured by the level of effectiveness. The effectiveness of the DPRD performance members can be seen from how far they can carry out the functions inherent in their bodies i.e. the functions of legislation, supervision and budget. Effectiveness is very important in the work of legislative members. Effectiveness is carried out in order to achieve the objectives of public organizations related to the technical rationality, values, mission and objectives of the organization and the function of development agents. ${ }^{32}$ A common problem that occurs with the legislative in this country is their inability to complete targets in making laws or local regulations (Perda). One of the causes is due to their careless toward the effectiveness of dimension. Every year, $D P R D$ Ponorogo, through its initiative rights, sets a target of making 7 regional regulations. Unfort unately, in practice they can only produce 3 regional regulations in the 2009-2014 periods. It shows their ineffectiveness.

The contribution of women legislative members in general matters can be categorized to be the same as male legislative members. All legislature members and even parties contributed to create development through physical programs. The physical programs

${ }^{32}$ Wahyudi Komorotomo, Sistem Informasi Manajemen dalam Organisasi Publik (Yogyakarta: Gadjah Mada University Press, 1998), 25. 
were directed to their constituents and their chosen regions. Hence, both men and women, one party and the others equally getting the proportional program or social assistance that was used to build the society that has delivered them as board of DPRD. Some of their contributions include; creating industrial houses, building roads, repairing gutters, building public facilities, etc. and contributing to making laws or regulations and implementing guidance toward the executive.

The contribution in empowering women that are programmatic seems to be very small. In the context of legislation, their contribution to create and legalize local regulations that support women's empowerment is unsuccessful. Local regulations related to women migrant workers and trafficking which is important to protect women was still neglected. Apart from their small numbers, the lack of an agreement about shared perception of the regulation importance matters. Asymmetric perception among them created the disunity in fighting for the rule. This lack of cohesiveness is likely to be swayed by male legislators to confront it.

Another political contribution was by giving part of their salary to the party each month. According to them, this financial contribution is believed contribute to the party in order to accommodate the aspirations of the people and then fight for the publics' needs. This contribution is intended to run the party machine in carrying out its objectives to approach and influence the society to enter its carriage in developing the nation and state.

Their contribution to women's empowerment in sectors other than the economy was very small. Indeed, some associations had been formed like women farmer's groups, but this association seemed only to strengthen their political legitimacy among women farmers, or merely to fulfill the requirements for disbursement of existing programs. Some programs that are needed by women related to empowering their lives can be done through several aspects, such as economics, socio culture and so on. Empowerment in those sectors must be specifically intended to empower not to strengthen political legitimacy.

Some obstacles faced by women parliamentarians in working and realizing their contribution to women empowerment includes the strengthening of patriarchal culture that still surrounded legislators 
and made women legislators powerless to do something. ${ }^{33}$ In many meetings, their proposals related to women empowerment were always hampered by the attitudes and behavior of male legislative members. The strengthening of this culture can complicate the efforts of women legislative members to empower women. As a result, their contribution and role to the community could not be realized maximally. Besides, related to the roots of patriarchal culture is the policy that arises from parties that do not consider the mandate of the law which encourages the existence of affirmative action in the form of women's representation in parliament as much as $30 \%$.

In addition, the lack of coordination among women legislators was mainly because they were lost in the party's interests. Furthermore, the party leaders and legislative leaders controlled by these men considered that general physical programs were more important than women empowerment programs, because in the physical development program women would get the benefits too. Along with these conditions the coordination between them did not work so that the spirit of their struggle to improve the fate of women was covered by the public interests outlined by the party. This lack of good coordination was also caused by differences in the level of understanding, intellect and spirit among women parliamentarians.

Moreover, the pattern of relations with the society was built on a transactional basis. The programs were given because of an agreement made during the campaign period. Through this pattern, the society would get a program only if they voted the legislative candidates. The programs provided to the society are no more than remuneration, formalities and tend to be consumptive even though the program is productive. Therefore the program did not run well, but to be enjoyed together. This can be seen through some program reports which are not relevant to the results, even fictitious.

In addition to transactional, programs carried out were full of political content. The program was given to society in order to be re-elected at the next election. Therefore these programs are actually just a lipstick or "down payment" to strengthen political legitimacy in society. The political goals that sneaked in the social programs caused the legislators not to be creative in making programs. They

${ }^{33}$ Aisah Putri Budiatri, "Bayang-bayang Afirmasi Keterwakilan Perempuan di Parlemen Lndonesia,” Jurnal Studi Politik Studi Politik 2, no. 1 (2011): 97-99. 
were not able to create sustainable empowerment programs. Maybe these programs were considered to spend much cost, time and energy. Therefore, their performance has weakened, so that their contribution to society, especially for women, could not be seen.

\section{CONCLUSION}

The results of this study concluded that the performance of women legislative members was less satisfactory. This can be seen from 3 aspects; responsiveness, accountability and effectiveness. In the aspect of responsiveness, women parliamentarians were lack of understanding toward society's aspirations related to the importance of realizing the regulations on the protection of women migrant workers and anti-trafficking. Their responsiveness to visit the constituents and approaching the community to listen to people's aspirations was blurred, because the goals were filled with nuances of political benefits. In the aspect of accountability, generally, women legislators maintained a culture of uncontrolled revenge. As for the aspect of effectiveness, they were not able to meet the target to accomplish the local regulations that governed society. They accomplished 3 of 7 local regulations only in a working period. Their supervision toward development projects by the executive was not effective. In fact, many of the projects were not implemented properly according to the rules and many of them violated the specified deadline.

Generally, contributions of women parliamentarians are carried out in accordance with their main tasks and functions. Their contribution which is more specifically for women's need is their proposal to accept and agree on regional regulation about women migrant worker and trafficking. However, this contribution has not appeared. The other contribution is their active participation in attending women's organization activities. However, this activity is more political than practical. It can be said that through the visit and mentoring they only expect returning the favor rather than carrying out a process of empowerment in the form of regeneration which has significance for the continuation of his political career. Their contribution to the political party is the most realistic. They contributed part of their fees every month to the party. Some of them contributed to the economic empowerment program. Unfortunately, the program was only limited to the surface, not the actual 
empowerment that can create social change and women's economic independence.

Some obstacles faced by them in realizing good performance and contribution to women involve (a) the strong patriarchal cult ure in the legislative environment which made them powerless to develop their ideas and programs, (b) weak coordination among women legislative members, which was caused by the focus on social programs in which women were already there to experience the benefit and differences in insight and intellect that resulted in disunity of their fighting spirit, (c) the pattern of relationships that were built based on transactional basis, which caused women empowerment programs to be no more than reciprocated and consumptive, and (d) politically charged programs, where social programs were provided with the aim of legitimacy and guarantee the political continuity.

\section{REFERENCES}

Amalia, Luky Sandra. Perempuan, Partai Politik, dan Parlemen di Indonesia: Suatu Analisis. Jakarta: PT. Gading Inti Prima, 2012.

Arbi Sanit. Perwakilan Politik di Indonesia. Jakarta: Rajawali Press, 1985.

Budiatri, Aisah Putri. "Bayang-bayang Afirmasi Keterwakilan Perempuan di Parlemen Lndonesia.” Jurnal Studi Politik Studi Politik 2, no. 1 (2011).

Cipto, Bambang. Dewan Perwakilan Rakyat. Jakarta: RajaGrafindo Persada, 1995.

Dharma, Surya. Konsep dan Teknik Penelitian Gender. Malang: UMM Press, 2002.

“Dewan Perwakilan Rakyat.” Accessed November 16, 2019. http:// www.dpr.go.id/.

Dwiyanto, Agus. Reformasi Birokrasi Publik di Indonesia. Yogyakarta: Pusat Studi Kependudukan dan Kebijakan, 2002. 
Elisabeth AD Haryono. "Bagaimana Wajah Caleg Perempuan dalam Pemili 2014.” Yayasan Jurnal Perempuan, May 2014.

Fahmi, Irham. Manajemen Kinerja: Teori dan Aplikasi. Bandung: Alfabeta, 2013.

Faisal, Sanapiah. "Pengumpulan dan Analisis Data dalam Penelitian Kualitatif." In Analisis data Penelitian Kualitatif, by Burhan Bungin. Jakarta: RajaGrafindo Persada, 2010.

Gaffar, Afan. Politik Indonesia: Transisi Menuju Demokrasi. Yogyakarta: Pustaka Pelajar, 2000.

Hardjaloka, Loura. "Potret Keterwakilan Perempuan dalam Wajah Politik Indonesia Perspektif Regulasi dan Implementasi." Jurnla Konstitusi 9, no. 2 (2012).

Haryono, Elisabeth Anita Dhewy. "Bagaimana Wajah Caleg Perempuan dalam Pemilu 2014?" Yayasan Jurnal Perempuan, May 2014.

Imawan, Riswandha. Faktor-faktor yang Menghambat Usaha Optimalisasi Peran Dewan Perwakilan Rakyat RI dalam Fungsi Legislatif, dalam Sistem Politik Indonesia,. Jakarta: Rajawali Press, 1993.

Komisi Pemilihan Umum Kabupaten Ponorogo. "Pengumuman Nomor: 701 /PL.01.9-Pu/3502/KPU-Kab/VII/2019 Tentang Pengumuman Penetapan Calon Terpilih Anggota Dewan Perwakilan Rakyat Daerah Kabupaten Ponorogo Pemilihan Umum Tahun 2019," July 22, 2019.

Komorotomo, Wahyudi. Sistem Informasi Manajemen dalam Organisasi Publik. Yogyakarta: Gadjah Mada University Press, 1998.

Mastuti, Sri and Rinusu. APBD Responsif Gender. Jakarta: CiBa, 2003.

Mahsun, Mohamad. Pengukuran Kinerja Sektor Publik. Yogyakarta: BPFE, 2013.

MB. Wijaksana. Modul Perempuan Untuk Politik. Jakarta: Yayasan Jurnal Perempuan, 2004. 
Miles, Matthew B., and AS. Michael Hubermans. Analisis Data Kualitatif. Translated by Tjetjep Rohendi Rohidi. Jakarta: UI Press, 1992.

Muhadjir, Noeng. Metodologi Penelitian Kualitatif. Yogyakarta: Rake Sarasin, 1996.

Mukarom, Zaenal. "Perempuan dan Politik: Studi Komunikasi Politik Tentang Keterwakilan Perempuan di Legislatif." Mediator 9, no. 2 (2008).

Nimrah, Siti, and Sakaria. "Perempuan dan Budaya Patriarki dalam Politik (Studi Kasus Kegagalan Caleg Perempuan dalam Pemilu Legislative 2014 ).” Jurnal The Politics 1, no. 2 (July 2015).

N.K., Denzin, and Lincoln. Handbook of Qualitative Research. London: Sage Publications, 2000.

Nugraheny, Dian Erika. "KPU: 118 Perempuan Terpilih Jadi Anggota DPR 2019-2014." Republika.co.id, September 2019.

Nurhayati, Sri Puji. Kinerja Lembaga Legislatif (Studi Analisis Kinerja DPRD Kota Medan Periode 2004-2009). Sumatera Utara: Universitas Sumatera Utara, 2010.

Pramono, Sidik. Meningkatkan Keterwakilan Perempuan. Jakarta: Kemitraan bagi Pembaruan Tata Pemerintahan, 2011.

Prawirosentono, Suyudi. Kebijakan Kinerja Karyawan: Kiat Membangun Organisasi Kompetitif Menjelang Perdagangan Bebas Dunia. Yogyakarta: BPFE, 1992.

Pusat Kajian Ilmu Politik. Naskah Rekomendasi Kebijakan: Representasi Perempuan dalam Regulasi Partai Politik dan Pemilu. Jakarta: Pusat Kajian Ilmu Politik Universitas Indonesia, 2010.

Rahayuningtyas. "Perempuan dan Pembuatan Kebijakan di DPR RI.” Presentation, Jakarta, April 26, 2012.

Shyedoya, Nadezhda. Perempuan di Parlemen. Jakarta, 1999.

Soetjipto, Ani Widyani. Politik Perempuan Bukan Gerhana. Jakarta: Penerbit Buku Kompas, 2005. 
Wargadinata, Ella. "Kualitas Pengukuran Kinerja Organisasi Publik.” Sosiohumaniora 19, no. 2 (July 2017).

Wicaksono, Kristian Widya. "Akuntabilitas Organisasi Sektor Publik." Jurnal Kebijakan dan Administrasi Publik 19, no. 1 (mey 2015). 